\title{
What Happened to Gender and History?
}

Qu'est-il arrivé au genre en histoire?

Deborah Thom

\section{(2) OpenEdition}

Journals

Electronic version

URL: http://journals.openedition.org/rfcb/5978

DOI: $10.4000 / \mathrm{rfcb} .5978$

ISSN: 2429-4373

\section{Publisher}

CRECIB - Centre de recherche et d'études en civilisation britannique

\section{Printed version}

Date of publication: 1 April 2008

ISSN: 0248-9015

\section{Electronic reference}

Deborah Thom, «What Happened to Gender and History? », Revue Française de Civilisation Britannique [Online], XIV-4 | 2008, Online since 01 April 2008, connection on 20 September 2020. URL : http:// journals.openedition.org/rfcb/5978; DOI : https://doi.org/10.4000/rfcb.5978

This text was automatically generated on 20 September 2020

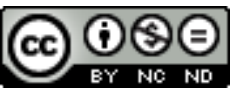

Revue française de civilisation britannique est mis à disposition selon les termes de la licence Creative Commons Attribution - Pas d'Utilisation Commerciale - Pas de Modification 4.0 International. 


\title{
What Happened to Gender and History?
}

Qu'est-il arrivé au genre en histoire?

\author{
Deborah Thom
}

1 Thus wrote Virginia Woolf in 1928 in the talk later published as A Room of One's Own. This author's essay on the subject of the contrast between feminist history and women's history assessed the state of play ${ }^{1}$ in 1992. There I argued that the task of women's history had been amply fulfilled by extensive research into the material details of everyday life. Women's history had developed from social history on the one hand and from left politics on the other. Sheila Rowbotham, writing first her Women Resistance and Revolution in 1972 about women radicals, then her influential Hidden from History in 1973 which had the subheading 300 years of women's oppression and the fight against it, thus began a project of recording and reviving a radical tradition of British feminism which she has continued until the present. She had demonstrated the ways in which women's contribution to alternative left cultures had been ignored at the time and obscured in the historical record. She wrote about birth control campaigners, sexual radicals, trade unionists and socialists. This analysis was continued in her Women's Consciousness, Man's World which was published by Penguin, unlike the earlier work which had originally been published by a left-wing publishing house, Pluto Press, in 1973. British feminism has always been remarkably historical in its focus and search for origins and her contribution helped to create a new culture of historical research and publishing as well as the development of university courses in women's history and publishing projects in several academic and mainstream publishers. Other historians developed similar studies with the focus often on the reclamation of unsung heroism. Histories of prostitution, social purity, feminism, education and birth control were the product of this vigorous period of women's history publishing. ${ }^{2}$ These studies began to appear across the Atlantic as well, especially the work of writers like Judith Walkowitz on prostitution, Deborah Gorham on child prostitution and intellectual historians like the literary scholars Jane Marcus and Elaine Showalter. These histories in general celebrated women's achievements, recovered the obscure and secret histories of 
women's activities and criticized the male stream tendency of most conventional history which ignored what women were doing or saw it as insignificant. Thus the development of women's history encouraged new methods of historical enquiry, especially the use of oral history and historical ephemera as sources as much as official documents.

2 This period of rediscovery and celebration was called into question by the discursive histories of writers who began to suggest that experience was a problematic basis for a social history which accepted the sexual division of Victorian society as a lived reality. Denise Riley in Am I That Name argued that history's job was to disturb the ground on which it stood. Some feminist theorists went further than this in arguing that all histories were a product of the writer rather than an exposition of an actual past. Very few histories were written based upon this theory as British historians remained wedded to an essentially political claim to authenticity and truthfulness. Although cultural and intellectual history increased in the 1980s it remained in general true that women's history continued to attempt to rediscover and to celebrate rather than analyse the psychic structures of oppression. This often had interesting consequences. One debate that continues to be controversial was over the question of the 'family wage'. Trade unionists and some social reformers in the $19^{\text {th }}$ century argued that wages should allow for the family responsibilities of the worker. Others argued that this claim perpetuated female dependency. Similarly, historians have continued to look at the relationship between women's waged work and social conditions and some have concluded that such work was indeed potentially damaging to life expectancy - others have argued that the lack of such work was far more damaging.

3 Social history also called into question the idea of the family as either a place of nature and of safety, seeing it as a place of danger through discussion of divorce, domestic violence and child abuse. The influential study by Leonore Davidoff and Catherine Hall, Family Fortunes, looked at the family as the site of reproduction of fundamental social attitudes and argued that the newly emergent urban middle class helped to transform social relationships at the beginning of the $19^{\text {th }}$ century. Amanda Vickery challenged this narrative on two grounds. First she argued that the rhetoric of a domestic ideology did not reflect the lived reality of a social life in which men and women did not inhabit separate spheres. Secondly she argued that women were not oppressed by social exclusion but on the contrary developed influence in many social activities despite a lack of formal political rights. In some respects the discussion of separate spheres reflects the richness and diversity that taking gender formation seriously creates. Both parties agree that attitudes to gender roles and activities are varied and change over time even if they disagree about inequality and timing. What Davidoff and Hall's work still raises is the difference between looking mostly at women, as Vickery does, or looking at men as well in which gender becomes a constraining and shaping force for both sexes. Neither work assumes female weakness or oppression as older women's history tended to do. ${ }^{3}$

4 The task of a more political history of the discourses of gender had not then been much elaborated. There was a detailed and extensive narrative of the language of the politics of the suffrage agitation but the historiography since has moved on here quite substantially. Histories of feminism have investigated the processes of organization and agitation. Sandra Stanley Holton noted the significance of a common language of democracy and common practices of agitation away from the metropolitan spotlight in 
a history which showed a more fluid and contingent politics on the ground. Others have criticised the idea of a unity of feminism arguing for a variety of voices and contested notions of identities, for example, Lucy Delap, who wrote recently about the feminist avant-garde, some of whom were critical of the vote as a distraction from the real task of psychological emancipation, especially those around the journal Freewoman. ${ }^{4}$ Denise Riley's poetical and critical comments upon the notion of identity in her Am I That Name published in 1988 began the process of destabilizing the notion of a sex identity as an easy, simple thing to do and made it increasingly difficult for any historian to write about women as if the assumption of difference was always an easy option in argument. She wanted to call into question the ideas of experience itself, recognizing that gender is a discursive category and, as Judith Butler was to add, a performative art. This deconstructive approach led to some valuable insights in political theory and political history. It was also much criticised by those who wished to argue that the historian can rediscover factual material about the lives of the past, that past actors do not just articulate hegemonic discourse but their lives can be interrogated as Woolf had argued. Joan Scott in Feminism and history extended this challenge to the concept of identity as always enabling or ennobling in writing about women (and, by implication, about men). She has continued to write about the development of a history which examines contested notions of difference rather than an assumption that gender is ever fixed and clear. In her recent work on French universalism she has repeated the challenge to argue that gender is always a political construction:

But I would also insist that France is a particular example of a more general proposition: histories that focus on sexual difference cannot be written apart from the histories of politics within which they take shape and to which they in turn give form, whereas histories of politics are often illuminated by feminist critiques that, at their best, uncover contradiction and exacerbate it in an effort to transform the status quo.

5 The history of gender and history has become a more settled phenomenon than it was nearly twenty years ago when the journal Gender and History was founded. ${ }^{6}$ Courses of history and gender and women and history have multiplied in the Anglophone universities where the subject has been most discussed. The contrast with other areas of social history is visible and stark. Courses in economic history and labour history are folding while cultural and political histories of gender multiply. However areas of new work remain patchy and partial.

6 Social history has added to the narratives of everyday lives using new sources or old sources in a new way to bring us the history of women that Woolf asked for. ${ }^{7}$ Hera Cook returned to the vexed question of the adoption of birth control and its social and sexual effects. She insists that the body and sex itself need to be reinstated in the history of demography and that the contraceptive pill was emancipatory because it made sex without anxiety possible. ${ }^{8}$ Here the Foucauldian attack on concepts of improvement or development as new forms of psychic control is being rejected in favour of a return to a discourse of progressive change because of the way in which one sex, the female, was affected by this new development. Kate Fisher and Simon Szreter in their accounts of married sexual practices reinstate the married couple as taking joint decisions about whether or when to use forms of birth control when coitus interruptus was the only easy contraceptive option. ${ }^{9}$ These can be reconciled as soon as the differences of timing are considered. The inter-war period saw a pessimism about the future because of 
economic decline, declining birth rates and delayed marriage while post war saw a short lived reversal of these trends as well as an increase in the education and professional employment of women. Cook's long view wants to assert the significance of sexual desire in the lives of women but there are problems in the discursive evidence she offers as part of the problem for historians is that sex, as such, was difficult for women to speak about before Marie Stopes helped to make it easier with the publication of Married Love in 1918. Women could talk about motherhood, health and pregnancy as well as about prostitution and sex trafficking as social evils but they could not, in British cultures, offer much description of sexual feelings or desires. Lesley Hall has described the change in making sex speakable as a result of books and publicity arising from Stopes' work in her interesting attempt to describe the period after $1880 \mathrm{a}$ decade at a time, Sex, Gender and Society, and she, too, argues for a change in the capacity to express emotion or desire but sees it in both sexes..$^{10}$ In many ways history has here moved back to the emotions and sensibility and people begin to investigate notions of love. This was one of the strongest claims of Francoise Barret Ducroq in Love in the Time of Victoria, which used the archives of Coram's hospital to describe the mixed fortunes of the mothers of the foundlings left at the Foundling Hospital. Here the mothers who left their children used the discourse of shame and repentance to describe their actions but asserted the value and significance of love as an explanation for their fall. The social control discourses of earlier accounts of these narratives have been replaced by a more nuanced anthropological account of the ideas of marriage or courtship and a consequent expansion in the historical research that looks at poor mothers as more actors and agents than victims and sufferers. The reductive social history of bastardy is given a valuable corrective here in recording the attitudes to sexuality of the women themselves albeit within a discourse framed by the paramount need to benefit their infants.

7 The study in women's history of femininity and the changing construction and experience of womanhood continues to be productive. Selina Todd, for example, studied the young women of the interwar and postwar period. ${ }^{11}$ She looked at their family lives, domestic obligations and workplace activities as well as their leisure pursuits. She tracked the key choices of everyday life: when and where to work, whether and when to marry and who to choose as companions in social life. This exemplary mapping of young women making their own history in circumstances not of their choosing demonstrates the complexity and richness of a history in which the process of living with a gendered identity changes over time. These women began the period which she describes as domestic servants and end it as office workers. Other studies have looked at domestic service itself, at household labour, at factory workers and at rural women - all demonstrating an acute understanding of the processes of historical change. ${ }^{12}$ The twentieth century saw dramatic change in the labour market participation of women as well as the contribution they made to household labour and this history is extensive and growing although the sheer difficulty of considering the idea of class in relation to gender remains a problem.

8 Fatherhood and masculinity have become increasingly important. John Tosh summed this up in his path-breaking account of the Victorian bourgeoisie in Manful Assertions and has since followed this with Masculinity And The Middle Class Home. In his recent collection he has explained the ambition of his project which is to rewrite the nature of historical enquiry by placing gender at the forefront of all historical writing: "Rather, it is a new perspective which potentially modifies our view of every field of history in 
which men are the principal subject - which is to say the overwhelming majority of written history." 13

Martin Francis assessed the state of play in his review article on masculinity in the Historical Journal..$^{14}$ Here he argued that manhood had become less a problem and more a terrain of contested ideas about what it was to be a man. Men looked more fragile, less certain of their power or their identity as husbands, lovers or fathers. While this poses a valuable question about a history which ignores masculinity these works come quite close to suggesting that men have more difficulties in history than women. The old understanding that came out of attempts to understand early $20^{\text {th }}$ century feminism seems to have become hidden in the resurrection of a new, gendered history of the emotions. Michael Roper has argued that masculinity is better understood as a process of navigating cultural scripts, an approach that helps in understanding gender processes in both sexes and at all ages.

What emerges from a study of subjectivity in war memoirs is, by contrast, a view of masculinity as a process in which social scripts are negotiated, one on another, within the self. Roper continued with a plea for more careful consideration of men as victims as seen in the war literature about shell shock:

Pregender conceptualizations of masculinity certainly lacked an adequate account of power and of the social and cultural contexts within which gender identities are formed, being, as it were, rather narrowly focused on individual emotional processes. They also tended to equate the masculine with the universal. ${ }^{15}$

11 Here feminist accounts of the psychic life of power have been redeveloped to show how far fixed notions of gender - gender as a thing, a stereotype - help people to construct and reconstruct different ideas of gender behaviour.

Postmodern history has developed a critique of the notion of experience which argues that the concept of gender is a constantly reconstructable performance. Work has been done on the idea of etiquette and deportment in Cambridge undergraduates, portraits of Victorian business men and civic dignitaries, royalty and the idea of identity which generates new methods of showing off gendered characteristics. New work on the history of dress, especially underwear has followed on this mode of examining how people produce their own images of appropriate gender behaviour in a heavily gendered context. ${ }^{16}$ Nineteenth century painting ${ }^{17}$ provides a particularly rich source of such material as does twentieth century photography. ${ }^{18}$

13 Sexuality and play have become strong features of historical practice investigating gender relations. Class keeps coming back into historical research by way of leisure pursuits and discussions of respectability. The argument about production being replaced by consumption carries forward the question of gender into this new area of research. Women in twentieth century Britain predominate in investigations of reading, cinema going, shopping carried out at the time as well as those of historians. The pub on the other hand remained predominantly a male resort until the 1980 s. Gareth Stedman Jones looked at the songs of the music hall when discussing the language of class and Peter Bailey has used the same sources. Neither put gender at the forefront of their account but it is there nonetheless because of the need to explain the ludic elements of the history of leisure and examine their significance.

Cultural history has turned more to institutional construction and production in recent years. Gendered social spaces have become objects of interest. Leonore Davidoff's The Best Circles $^{19}$ was a model of this sort of account where social institutions became a place 
in which gender was rehearsed and produced in highly ritualized ways with explicit codes of behaviour recorded and displayed in shared elite understandings of the way the debutante was to behave in her entry into the marriage market. Others have since followed looking at gentlemen's clubs, the lives and biographies of highwaymen and the ideas of caricature and laughter. ${ }^{20}$ Vic Gatrell's account of satirical prints in particular reintroduces a chronology in which he sees a liberal, tolerant and libidinous culture being succeeded by an age of cant and Victorian morality which is more loss than gain. Here male gender is being described as transformed by the rise of respectability and Puritanism about the body. This debate reflects the widespread use of Norbert Elias' concept of 'the civilizing process' in accounting for major cultural shifts in thinking about periodisation. Francoise Thébaud's suggestion that men and women have different chronologies has been little taken up in this set of reflections; and nor has the debate over universalism versus particularism been very influential in British history. ${ }^{21}$

Suffrage has generated some of the most effective and scholarly work in British history about the politics of gender. The subject was at the centre of much of the early work on women's history but the critical assumption of much recent work has been productive in generating more general questions about the periods and places in which gender becomes an essential part of debate. Jill Liddington has continued to investigate the provincial history of suffrage in her Rebel Girls: Their Fight for the Vote published by Virago Press in 2006. The story of the working class supporters of the suffrage campaigns calls into question the separation between advocates of equality and difference and gives interesting insights into the political process carrying on the differentiation between sorts of political campaigning begun by Liddington herself in her One hand tied behind her written with Jill Norris. Both books were published by the same publishing house, Virago, which has been publishing new material since 1973 and producing reprinted classic books by women since 1976, some of which are themselves valuable historical sources. Women's history and gender history have been less opposed than is sometimes assumed in this persistent debate about the way in which women claimed and won the franchise. One substantial research project generated a study of men's contribution to the struggle for the vote, The Men's Share?: Masculinities, Male Support and Women's Suffrage in Britain, 1890-1920 by Angela V. John and Claire Eustance.

The other consistent contribution to thinking about gender has been the history of war. Here discussion about masculinity, femininity and warfare has looked at the embodied experience of the trench soldier ${ }^{22}$, compared the contributions of men and women to the ideology, memorialisation and history of the war ${ }^{23}$ and increased and reflected upon the use of oral history. ${ }^{24}$ The theoretical questions raised by many about the way in which the direct evidence of participants through memoir, diary or oral history reflect changing interpretations of war has a direct relevance to the history of gender because the idea of subjectivity is problematic faced with substantial popular memories of the period. War raised gender directly through the development of conscription and national service as well as the management of an expanded war economy and the direction of labour. From the beginning of the first world war government propaganda used gender to encourage young men to volunteer for military service with a poster reading 'Women of Britain say, "Go".' These histories have emphasized the way in which warfare places explicit demands on the bodies of both men and women, encouraging both to reproduce and to fight. Here experience is 
as important as mentalities in relocating gender back into the body. Summerfield's critique of her own earlier work has led her back to the Second World War as a period which has created mythologies that people continue to tell themselves. In the end men and women both have different wars in which they recount the experience, as Summerfield suggests, with different memories framing their accounts of the experience. She separated her 42 witnesses into the heroic and the stoic and thus suggested that the interpretation of the war experience needs to be understood as more subtle and complex than simply one in which the two genders see the war in different ways. What she does not query is the suggestion that gender remains central to people's reflections upon the work experience of war because it was constitutive of work grading, payment and public recognition. Feminism remained central to this professional practice in that there remained an impulse to describe that which had been hidden in the contemporary record or which was unrecognized by early histories because it was thought it was undervalued at the time. But feminist practice has also informed the understanding of gender in general in the recognition that gender relations are relations of power.

The journal Gender and History has been central to the development of the history of gender. It is now shared between Britain and the USA and continues with the express intention of expanding the subjects and authors of history beyond the Anglo-American English-speaking practice of history which has dominated gender studies. There are times at which the professional formation of historical study has lagged behind the non-professional histories. Much of the early work in the 1970s on women's history was located outside the academy - in the adult education movement, in school history, in popular publishing and in the mass media. Academic posts in women's history began to appear in universities in the 1980s and in the new century became quite common as did research funding for substantial projects in intellectual, social and cultural history. Posts in gender history have been rarer but the institutional basis has increased and now there are several professors of gender history. The subject remains controversial in some places but is firmly enough established to feel able to continue to expand in generating student programmes. It is now quite unusual for the idea that this is a legitimate object of historical enquiry to be questioned.

This survey of current objects of concern suggests that gender history is opening up sensitive expositions of mentalities, of epistemic changes and of that full social history that Woolf had asked for more than eighty years ago. How far it has redressed the balance between the interests of men and women that feminist historians hoped it would is less clear. Some historians of women have suggested that gender is a way of bringing men back into prominence - a way of challenging women's emergence as subjects of historical study. However the more successful characterization of the process would be that gender has been called into question for both sexes. While masculinity has been estimated anew as more vulnerable, less powerful and more conflicted than previous histories suggested, there remains a concern in gender history with topics like domestic violence and prostitution in which men tend to be naturalized and women seen as objects of historical rediscovery. The question of how far levels of violence have changed and whether men were more violent to women in the past has generated substantial research in the form of case studies and assessments of criminal statistics. 
19 In the end the plea for a new history of the unrecognized has largely been met. Imperial history has continued to look at subaltern studies, asking how far the experience of exclusion and oppression constructs the subordinate in new ways. The metropole has been to some extent decentered by the attempt to understand Empire as a web of ideas and experiences which interact. The suggestion that this volume of new historical enquiry might make history a little less lop-sided has not been so clearly answered. Gender studies do ask new questions, sometimes in new places and often in old ones, with productive effects. The institutional framework of the study of history in Britain has responded to these new challenges. There are now several courses in the history of gender in British universities and several professors of women's history or gender studies with a historical interest. PhD theses multiply as do books on the subject, both popular and academic. Indeed the concept of public history has been particularly productive in gender history in investigating the notions of public spheres and state formation. ${ }^{25}$ It has also been influential in thinking about participation in public activities in the sense of public history as the role of history in public life. The rise of family history has particularly influenced people's thinking about gender as it presents historical argument about family, the labour market, the effects of secular change in an accessible form.

Gender history is sometimes politically partisan, demonstrating a claim to the reader's attention that privileges the oppressed or the question of power in ways that presuppose an intellectual project as well as a political sympathy. However most is not based upon assumptions of identification or the primacy of sexed identity. Rather it calls the categories of gender into question and asks how far stereotypes of male or female behaviour can be seen in the historical record. Mostly the question of gender is seen as intrinsic to a proper understanding of the social as well as the political worlds that historians identify as their domain. Historians no longer argue along with Virginia Woolf for women as beings excluded from nations and the political world. In Three Guineas she wrote 'As a woman I have no country. My country is the whole world.' Women are now imbricated in discussions of a gendered polity as men are and historical study is the richer for it. However the political project of feminism remains germane to historical enquiry because people continue to ask Woolf's other question about how far a history can be valid that ignores slightly over one half of the human race. Gender remains a subject which can ask for the political implications of any event, movement or social phenomenon for men and women alike and gender historians continue to claim, often insistently, that both should be included in any rounded historical assessment. It should no longer be possible to equate the masculine with the universal. 


\section{BIBLIOGRAPHY}

BARRET-DUCROCQ, Françoise, L'amour sous Victoria: Sexualité et classes populaires à Londres au XIX siècle, Paris, Plon, 1989 ; traduction anglaise : Love in the Time of Victoria: Sexuality, Class, and Gender in Nineteenth-Century London, London: Verso 1991.

Birmingham Feminist History Group, 'Feminism as Femininity in the Nineteen-Fifties?' Feminist Review, $\mathrm{n}^{\circ} 3$, 1979, pp. 48-65.

BLACK, Amy and BROOKE, Stephen, 'The Labour Party, Women and the Problem of Gender, 195166,' Journal of British Studies 36, 1997, pp. 447-49.

BLAND, Lucy, 'In the Name of Protection: The Policing of Women in the First World War', in Julia BROPHY and Carol SMART (eds.), Women-in-Law: Explorations in Law, Family and Sexuality, London: Routledge and Kegan Paul, 1985, pp. 23-49.

BLAND, Lucy, Banishing the Beast: English Feminism and Sexual Morality,1885-1914, London, Penguin: 1995.

COCKS, H.G., "'Sporty" Girls and "Artistic" Boys: Friendship, Illicit Sex, and the British 'Companionship' Advertisement, 1913-1928', Journal of the History of Sexuality, 11, 2002, pp. 457-482.

COOK, Hera, The Long Sexual Revolution: English Women, Sex, and Contraception 1800-1975. Oxford: Oxford University Press, 2004.

COX, Pamela, Gender, Justice and Welfare: Bad Girls in Britain, 1900-1950, Basingstoke: Palgrave Macmillan, 2003.

COX, Pamela, 'Compulsion, Voluntarism, and Venereal Disease: Governing Sexual Health in England after the Contagious Diseases Acts', Journal of British Studies, 46, 2007, pp. 91-115.

D'CRUZE, Shani, Crimes of Outrage: Sex, Violence and Victorian Working Women, DeKalb: Northern Illinois University Press, 1998.

EUSTANCE, Claire and JOHN, Angela, The Men's Share? Masculinities, Male Support and Women's Suffrage in Britain, 1890-1920, London: Routledge, 1997.

GRAYZEL, Susan, Women and the First World War, London: Longman, 2002.

GRAYZEL, Susan, 'Liberating Women? Examining Gender, Morality and Sexuality in First World War Britain and France', in Gail BRAYBON (ed.), Evidence, History and the Great War: Historians and the Impact of 1914-18, New York and Oxford: Berghahn Books, 2003, pp. 113-135.

KENT, Susan Kingsley, Sex and Suffrage, Princeton: Princeton University Press, 1990.

KENT, Susan Kingsley, Making Peace: The Reconstruction of Gender in Interwar Britain, Princeton: Princeton Univerity Press, 1993.

LAITE, Julia Ann, 'The Association for Moral and Social Hygiene, Abolitionism, and Prostitution Law in Britain, 1915-1959', Women's History Review, 17, 2008 pp. 207-223.

LAMBERTZ, Jan, 'Feminism and the Politics of Wife-Beating', in Harold L. Smith (ed.), British Feminism in the Twentieth Century, Aldershot: Elgar, 1990, pp. 25-47.

LANGHAMMER Clare, 'Love and courtship in mid-twentieth century England' The Historical Journal, vol. 50, n 1, 2007, pp. 173-196. 
LEVINE, Philippa, 'Consistent Contradictions: Prostitution and Protective Labour Legislation in Nineteenth-Century England', Social History, 19, 1994, pp. 17-35.

LEVINE, Philippa, 'Rough Usage: Prostitution, Law and the Social Historian', in Adrian WILSON (ed.), Rethinking Social History: English Society 1570-1920 and its Interpretation, Manchester: Manchester University Press, 1994.

LEVINE, Philippa, “"Walking the Streets in a Way No Decent Woman Should”: Women Police in World War I', Journal of Modern History, nº6, 1994, pp. 34-78.

LEVINE, Philippa, Prostitution, Race and Politics: Policing Venereal Disease in the British Empire, New York: Routledge, 2003.

LEVINE, Philippa, “"A Multitude of Unchaste Women”: Prostitution in the British Empire', Journal of Women's History, 15, 2004, pp. 159-163.

LUDDY, Maria, Prostitution and Irish Society, 1800-1940, Cambridge: Cambridge University Press, 2007.

MARTIN, Francis, 'Tears, tantrums, and bared teeth: the emotional economy of three Conservative prime ministers, 1951-1963', Journal of British Studies, 41, 2000, pp. 354-87.

MARTIN, Francis, 'A Flight from Commitment? Domesticity, Adventure and the Masculine Imaginary in Postwar Britain’, Gender and History, vol.19 n 1, April 2007.

MARTIN, Francis, 'The Domestication of the Male? Recent Research on Nineteenth- and Twentieth-Century British Masculinity,' Historical Journal 45, no. 3, 2002, pp. 637-52.

MORT, Frank, Cultures of Consumption: Masculinities and Social Space in Late Twentieth-Century Britain, London and New York: Routledge, 1996, pp. 128-44.

MORT, Frank, Dangerous Sexualities: Medico-Moral Politics in England since 1830, London: Routledge, 2000.

PLUMMER, Kenneth, Documents of Life 2: An Invitation to Critical Humanism, London: Allen and Unwin, 2001.

RILEY, Denise, Am I That Name? Feminism and the Category of 'Women' in History, Basingstoke: Macmillan, 1988.

ROPER, Michael, 'Slipping out of view: subjectivity and emotion in gender history', History Workshop Journal, 59, 2005, pp. 57-72.

ROPER, Michael, "Between Manliness and Masculinity: The "War Generation" and the Psychology of Fear in Britain, 1914-1950' Journal of British Studies 44, no. 2 (2005), 343-362.

ROPER, Michael and John TOSH. 'Introduction: Historians and the Policies of Masculinity' in Manful Assertions: Masculinities in Britain since 1800, London and New York: Routledge, 1991.

SEGAL, Lynne, 'Look Back in Anger: Men in the 1950s,' in Rowena Chapman and Jonathan Rutherford (ed.), Male Order: Unwrapping Masculinity, London: Lawrence \& Wishart, 1988, pp. 68-96.

STEPHEN Heathorn, 'How Stiff were their Upper Lips? Research on Late-Victorian and Edwardian Masculinity’ History Compass, vol. 2, n 1, January 2004, pp.1-7

TOSH, John, A Man's Place: Masculinity and the Middle-Class Home in Victorian England. New Haven and London: Yale University Press, 1999. 
TOSH, John, Manliness and Masculinities in Nineteenth-Century Britain: Essays on Gender, Family and Empire. Harlow: Pearson Education, 2005.

WALKOWITZ, Judith R., 'The Indian Woman, the Flower Girl, and the Jew: Photojournalism in Edwardian London', Victorian Studies, 42, 1999, pp. 3-44.

WOOLLACOTT, Angela, “'Khaki Fever” and Its Control: Gender, Class, Age and Sexual Morality on the British Homefront in the First World War', Journal of Contemporary History, 29,1994, pp.

325-247.

ZEDNER, Lucia, Women, Crime and Custody in Late Victorian England, Oxford: Oxford University Press, 1991.

\section{NOTES}

1. Deborah THOM, ‘A Lop-Sided View: Feminist History or the History of Women?', in Kate CAMPBELL (ed.), Critical Feminism: Argument in the Disciplines, Buckingham and Philadelphia: Open University Press, 1992, pp. 25-51.

2. Jane RENDALL, Women in an industrialising society, England 1750-1880, Blackwell, 1990; Paula BARTLEY, Prostitution, prevention and reform in England, 1860-1914, London: Routledge, 2000; Kate FISHER, Birth Control, Sex, and Marriage in Britain, 1918-1960, Oxford: Oxford University Press, 2006.

3. Leonore DAVIDOFF and Catherine HALL, Family Fortunes: Men and Women of the English Middle Class 1780-1850, Chicago: University of Chicago Press, 1987; Amanda VICKERY, 'Golden age to separate spheres? A review of the categories and chronology of English women's history', Historical Journal 36, 1993.

4. Sandra Stanley HOLTON, Feminism and Democracy. Women's Suffrage and Reform Politics in Britain, 1900-1918, Cambridge: Cambridge University Press, 2003 (1986); Lucy DELAP, The Feminist Avant Garde: Transatlantic Encounters of the Early Twentieth Century, Cambridge: Cambridge University Press, 2007.

5. Joan Wallach SCOTT, Parité: Sexual Equality and the Crisis of French Universalism. Chicago: University of Chicago Press, 2005. Traduction française, Parité! L'universel et la difference des sexes, Paris : Albin Michel, 2005. p. 9

6. 'Why Gender and History?', Gender \& History 1 (1), pp. 1-6, 1989

7. General histories of gender and social change include textbooks on women in the $19^{\text {th }}$ century by Jane Rendall and Paula Bartley; Jane LEWIS, The Politics of Motherhood: Child and Maternal Welfare in England, 1900-1939, London: Croom Helm, 1980; Janes LEWIS (ed.), Labour and Love: Women's Experience of Home and Family, 1850 - 1940, Oxford: Blackwell, 1986; Lesley HALL's short survey on Sex, Gender and Social Change in Britain since 1880, London: Macmillan, 2000.

8. Hera COOK, The Long Sexual Revolution: English Women, Sex, and Contraception 1800-1975. Oxford: Oxford University Press, 2004.

9. Kate FISHER and Simon SZRETER, "They Prefer Withdrawal": The Choice of Birth Control in Britain, 1918-1950 Journal of Interdisciplinary History 34.2 (2003) 263-291

10. Lesley HALL, Sex, Gender and Social Change in Britain since 188, op. cit.

11. Selina TODD, Young Women, Work and Family in England 1918-1950, Oxford: Oxford University Press, 2005

12. Lucy DELAP, The Feminist Avant-Garde: Transatlantic Encounters of the Early Twentieth Century, op. cit; Andrew AUGUST, Poor Women's Lives. Gender, Work and Poverty in late-Victorian London, Madison, NJ: Fairleigh Dickinson University Press, 1999; Miriam GLUCKSMAN, Women Assemble: Women Workers and the New Industries in Inter-War Britain, London: Routledge 1990; Nicola VERDON, Rural Women Workers in Nineteenth-Century England: Gender, Work and Wages, Woodbridge: Boydell, 2002. 
13. John TOSH Manliness and Masculinities in Nineteenth-Century Britain: Essays on Gender, Family and Empire, Harlow: Pearson Education, 2005, p. 2.

14. Martin FRANCIS, 'The Domestication of the Male? Recent Research on Nineteenth- and Twentieth-Century British Masculinity,' Historical Journal 45, n 3, 2002, pp. 637-652.

15. Michael ROPER, 'Between Manliness and Masculinity: The "War Generation" and the Psychology of Fear in Britain, 1914-1950' Journal of British Studies 44, $\mathrm{n}^{\circ}$ 2, 2005, pp. 360-361. See also on the civil war Alexandra SHEPARD, 'From Anxious Patriarchs to Refined Gentlemen? Manhood in Britain, circa 1500-1700,' Journal of British Studies 44, n 2, 2005, pp. 281-295.

16. Christopher LAWRENCE, Steven SHAPIN (eds), Science Incarnate: Historical Embodiments of Natural Knowledge, Chicago: University of Chicago Press, 1998; Janet WOLFF and John SEED (eds), The Culture of the Capital: Art, Power, and the Nineteenth-Century Middle Class, Manchester: Manchester University Press; New York: St. Martin's Press, 1988; Almut JUNKER \& Eva STILLE, Zur Geschichte der Unterwäsche 1700-1960, Frankfurt: Historisches Museum, 1988; Cheryl BUCKLEY, Hilary Fawcett, Fashioning the Feminine: Representation and Women's Fashion from the Fin De Siecle to the Present, London: I.B.Tauris, 2001.

17. Marcia POINTON, Hanging the Head. Portraiture and Social Formation in Eighteenth-Century England, New Haven and London: Yale University Press, 1993; Lynda NEAD, Victorian Babylon: People, Streets and Images in Nineteenth-Century London. New Haven and London: Yale University Press, 2000

18. Judith R. WALKOWITZ, 'The Indian Woman, the Flower Girl, and the Jew: Photojournalism in Edwardian London', Victorian Studies, 42 (1999), pp. 3-44.

19. Leonore DAVIDOFF, The Best Circles: Society Etiquette and the Season, London: Croom Helm, 1973.

20. Robert B. SHOEMAKER, Gender in English Society, 1650-1850: The Emergence of Separate Spheres? London: Longman, 1998; Vic GATRELL, City of Laughter: Sex and Satire in Eighteenth-Century London, London: Atlantic books, 2007.

21. Michèle RIOT-SARCEY, 'The Difficulties of Gender in France: Reflections on a Concept,' Gender and History 11, no. 3 (1999), pp. 489-98; and Françoise Thébaud, 'Genre et histoire', in Christine BARD, Christian BAUDELOT et Janine MOSSUZ-LAVAU (dir.), Quand les femmes s'en mêlent: Genre et pouvoir, Paris: La Martinière, 2004, pp. 44-63.

22. Joanna BOURKE, Dismembering the Male: Men's Bodies, Britain, and the Great War. London: Reaktion Books, 1996.

23. Gail BRAYBON (ed.) Evidence, History and the Great War. Historians and the Impact of 1914-18, Oxford \& New York: Berghahn, 2004.

24. Penny SUMMERFIELD, Reconstructing Women's Wartime Lives. Discourse and Subjectivity in Oral Histories of The Second World War, Manchester: Manchester University Press, 1998, Lucy NOAKES, 'Gender, War and Memory: Discourse and Experience in History', Journal of Contemporary History, 2001, pp. 663-672.

25. Catherine HALL, Keith Mcclelland, and Jane RENDALL, Defining the Victorian Nation: Class, Race, Gender and the British Reform Act of 1867, Cambridge: Cambridge University Press, 2000.

\section{ABSTRACTS}

The project of putting women into history has developed through women's history into a substantial academic enterprise. Histories of women's everyday lives and their political 
contribution have multiplied and professionalized. However the study of gender has turned more recently to men and masculinity which has become seen as more troubled and fragile in the process of historical rediscovery. The question of feminism and the universal or particular claims to rights remains and requires further research into multiple differences rather than the assumption that difference exists and raising the question of how far a history of inequality can ever abandon the issue of gender entirely. The question of class and sexuality raises new areas of historical discussion which are being met by extensive research into performance and practise. Gender history is not a unity in that some historians still believe in binary difference while others reject the notion of identity as productive. Gender history remains an exciting and expanding field of study and should become a pertinent site of enquiry in other specialised histories.

A travers l'histoire des femmes, le projet de les replacer dans l'histoire s'est transformé en une entreprise universitaire importante. L'histoire de la vie quotidienne des femmes et de leur contribution politique s'est développée et s'est professionnalisée. Cependant, l'étude du genre s'est tournée plus récemment vers les hommes et la masculinité, qu'on voit maintenant, dans ce processus de redécouverte historique, comme plus conflictuelle et plus fragile. La question du féminisme et des revendications particulières ou universelles de droits subsiste et demande à être encore étudiée, en particulier dans ses différences multiples plutôt que dans le postulat que cette différence existe ; il faut poser le problème du point auquel une histoire de l'inégalité peut ou ne peut pas abandonner complètement la question du genre. La question de la classe sociale et de la sexualité soulève de nouveaux domaines de la discussion historique qui sont abordés par de larges recherches. L'histoire du genre n'est pas homogène dans la mesure où certains historiens croient toujours dans une différence binaire tandis que d'autres ne considèrent pas que la notion d'identité soit fructueuse. L'histoire du genre demeure un champ d'étude passionnant et qui se développe et devrait devenir un champ d'investigation pertinent pour d'autres sous-disciplines historiques.

\section{AUTHOR}

\section{DEBORAH THOM}

Robinson College, University of Cambridge 